\title{
Selection between LTA or FAU phases by manipulating the synthesis gel composition, crystallization time and temperature
}

\section{(Seleção entre as fases LTA ou FAU pela manipulação da composição do gel de síntese, do tempo e temperatura de cristalização)}

\author{
C. Corso ${ }^{1}$, M. M. Silva ${ }^{1}$, R. C. Santana ${ }^{1}$, K. D. Oliveira ${ }^{1}$, C. N. Avila-Neto ${ }^{1 *}$ \\ ${ }^{1}$ Federal University of Uberlândia, Faculty of Chemical Engineering, Av. João Naves de Ávila 2121, \\ 38408-144, Uberlândia, MG, Brazil
}

\begin{abstract}
LTA and FAU zeolites were synthesized with the addition of cetyltrimethylammonium bromide (CTAB) to assess the effects of $\mathrm{Si} / \mathrm{Al}, \mathrm{Na} / \mathrm{Al}$ and $\mathrm{H}_{2} \mathrm{O} / \mathrm{Al}$ ratios, time and temperature on the yield of each structure. The significance of each variable was determined by means of experimental designs, whose response variables were the areas of specific XRD peaks. CTAB did not act as a structure-directing agent, but rather as a growth modifier, increasing the growth rate of LTA and FAU crystals. At low temperature, LTA was afforded at low Si/Al ratio, while FAU crystallized at higher ratios, indicating a competition between the phases. Increasing temperature accelerated the kinetics of recrystallization of the less dense and metastable LTA and FAU phases in denser and more stable phases, such as sodalite and cancrinite. Decreasing the concentration of $\mathrm{Na}^{+}$and water reduced the crystallinity of both structures, while increasing the concentration of $\mathrm{Na}^{+}$favored LTA over FAU.
\end{abstract}

Keywords: LTA, FAU, composition of the synthesis gel, crystallization time, crystallization temperature.

\section{Resumo}

Zeólitas LTA e FAU foram sintetizadas com brometo de cetiltrimetilamônio (CTAB) visando avaliar os efeitos das razões $\mathrm{Si} / \mathrm{Al}$, $\mathrm{Na} / \mathrm{Al}$ e $\mathrm{H}_{2} \mathrm{O} / \mathrm{Al}$, do tempo e da temperatura no rendimento de cada estrutura. A significância de cada variável foi determinada através de planejamentos experimentais, cujas variáveis resposta foram as áreas de picos de difração de raios $X$ específicos. O CTAB não agiu como direcionador estrutural, mas sim como modificador de crescimento, aumentando a taxa de crescimento dos cristais. Em temperatura baixa, LTA foi obtida em baixas razões Si/Al, enquanto FAU cristalizou-se em razões maiores, indicando uma competição entre as duas estruturas. O aumento da temperatura aumentou a cinética de recristalização das fases LTA e FAU, menos densas e metaestáveis, em fases mais densas e mais estáveis, como sodalita e cancrinita. A diminuição de concentração de $\mathrm{Na}^{+}$e água reduziu a cristalinidade das estruturas, enquanto que o aumento de $\mathrm{Na}^{+}$favoreceu a formação de FAU em detrimento de LTA.

Palavras-chave: LTA, FAU, composição do gel de síntese, tempo de cristalização, temperatura de cristalização.

\section{INTRODUCTION}

Faujasite (FAU) and Linde Type A (LTA) are industrially important aluminosilicates extensively used in catalysis, adsorption and ion exchange processes [1-4]. The basic building unit of these materials is the sodalite cage (or $\beta$ cage). Structurally, the basic difference between LTA and FAU is the way the $\beta$ cages are connected. In LTA, the $\beta$ cages are linked via oxygen bridges by double fourmembered rings (D4R), forming $\alpha$ cages [5] with small pores of approximately $4.1 \AA[6]$. In FAU, the $\beta$ cages are linked to one another by double six-membered rings (D6R), forming the so-called 'supercage' [5] with pores of approximately $7.4 \AA[6]$. Due to their structural similarity, synthesis conditions such as aging time, crystallization time,

*avilaneto@ufu.br

(D) https://orcid.org/0000-0002-5835-6670 crystallization temperature, composition of the synthesis gel and type of structure-directing agent must be carefully laid down. A small variation of these conditions can lead to the formation of mixed (LTA+FAU) or unwanted phases. LTA is usually synthesized in the presence of tetramethylammonium cation $\left(\mathrm{TMA}^{+}\right)[7,8]$ or without a structure-directing agent (SDA) [9-14], although other surfactants are also employed [15]. In the case of FAU, the use of $\mathrm{TMA}^{+}[12,16,17]$ and crown ether [18] are reported, although the structure can also be obtained without structure-directing agent $[14,19$, 20]. Cetyltrimethylammonium bromide (CTAB) seems to be a promising structure-directing agent for the synthesis of zeolites. It has been successfully used to synthesize hierarchical LTA structures [21], to recrystallize zeolite Y and generate mesoporosity within the zeolite crystals [22] and to control both the size and morphology of LTA nanocrystals [23]. The cetyltrimethylammonium cation (CTA) was also used to synthesize siliceous MFI-type zeolite [24, 25]. 
Chawla et al. [25] demonstrated that the CTA-driven growth of MFI crystals can lead to a more uniform distribution of $\mathrm{Al}$ atoms within the particles.

Phase selection between FAU and LTA zeolitic structures was discussed in detail in some papers. Hu et al. [8] studied the influence of the concentration of $\mathrm{Na}^{+}$ions on the phase composition of the crystallization product using $\mathrm{TMA}^{+}$as structure-directing agent. It was found that pure LTA, pure FAU and the LTA/FAU ratio could be selectively synthesized by adjusting the $\mathrm{Na}^{+}$concentration in the initial solution. For instance, in syntheses performed with gel composition equal to $1 \mathrm{Al}_{2} \mathrm{O}_{3}: 4.36 \mathrm{SiO}_{2}: 2.39$ (TMA) $)_{2} \mathrm{O}: \mathrm{\beta Na}_{2} \mathrm{O}: 249 \mathrm{H}_{2} \mathrm{O}$, when the $\mathrm{Na}_{2} \mathrm{O}$ concentration ( $\beta$ ) was increased from 0.024 to 0.168 , the product gradually changed from pure FAU to pure LTA. A similar study [16] reported that increasing the concentration of $\mathrm{Na}^{+}$ions favors the formation of LTA over FAU, and that the resulting crystal size changes significantly. The reason for such behavior is that $\mathrm{Na}^{+}$plays the role of stabilizing the double four-membered rings of the LTA structure [26]. According to [27], the transition from pure LTA to pure FAU occurs gradually with increasing the $\mathrm{Si} / \mathrm{Al}$ ratio from 0.5 to 5 . Besides, this study revealed a narrow multiphase region located around $\mathrm{Si} / \mathrm{Al}=1.2$. According to the authors, increasing the amount of water (in their case, from $11 \mathrm{NaOH}: 190 \mathrm{H}_{2} \mathrm{O}$ to $11 \mathrm{NaOH}: 348 \mathrm{H}_{2} \mathrm{O}$ ) increases the amplitude of this multiphase region. These results agree well with a thermodynamic solution model proposed in [28] that takes into account the solubility product for the condensation of silica and alumina to produce a zeolite of composition $\mathrm{NaAlSi}_{\mathrm{n}} \mathrm{O}_{2 \mathrm{n}+2}$, where $\mathrm{n}$ is the $\mathrm{Si} / \mathrm{Al}$ ratio of the dry solid.

The phase transformation of zeolitic materials as a function of the crystallization time can be explained by the Ostwald rule of stages [27]. In this phenomenon, different kinetic paths lead to the initial formation of thermodynamically metastable structures that undergo successive recrystallizations over time in order to form ever more stable structures. Accordingly, the sequence of stages should progress from low (less stable) to highdensity (more stable) structures. The diagram constructed by Maldonado et al. [27] exemplifies this process very well. They showed that phase transformations in Si-rich solutions $(\mathrm{Si} / \mathrm{Al}>2)$ tended to follow the sequence FAU (less dense/ stable) $\rightarrow$ GIS $\rightarrow$ ANA (more dense/stable); while phase transformations in Al-rich solutions $(\mathrm{Si} / \mathrm{Al}<1)$ tended to follow the sequence LTA (less dense/stable) $\rightarrow$ SOD $\rightarrow$ CAN (more dense/stable). However, in syntheses using higher $\mathrm{Si} / \mathrm{Al}$ ratios, some works [27, 29] report situations in which the LTA zeolite is initially formed, followed by an intercrystalline transformation to FAU (less dense and hence less thermodynamically stable than LTA), which contradicts the Ostwald rule of stages. The explanation for this situation was given by Oleksiak et al. [29]. They observed that growth solutions aged at room temperature for $48 \mathrm{~h}$ still contained undissolved silica particles, and that these particles were formed by a core-shell structure comprising a Si core and an Al-rich shell. In these cases, as nucleation occurred near the particle shell, in a region where $\mathrm{Si}$ accessibility was restricted, the environment was not representative of the overall molar composition of the growth solution. Instead, the composition of the solution in the regions close to the particle shell was similar to the composition of the syntheses performed with low $\mathrm{Si} / \mathrm{Al}$ ratio. Consequently, the initial obtaining of the LTA phase followed by the intercrystalline transformation to FAU is plausible under these conditions, as the growth solution becomes progressively enriched with silica with time.

This paper aims to assess how the selection between LTA and FAU phases in the crystallization product of syntheses carried out with CTAB is influenced by the synthesis conditions: crystallization time, temperature and the ratios $\mathrm{Si} / \mathrm{Al}, \mathrm{Na} / \mathrm{Al}$ and $\mathrm{H}_{2} \mathrm{O} / \mathrm{Al}$. Three experimental designs were performed in which the response variables evaluated were the areas under X-ray diffraction peaks representative of each zeolite framework. Based on these results, the crystallization product could be controlled to obtain either FAU or LTA, or a FAU/LTA mixture with different LTA/FAU ratios by adjusting the synthesis conditions. Samples were characterized by X-ray diffraction (XRD), thermogravimetric analysis (TGA) and scanning electron microscopy (SEM).

\section{MATERIALS AND METHODS}

Hydrothermal synthesis: all syntheses were carried out with a hydrothermal methodology adapted from the literature [30]. The synthesis started with dissolving a proper amount of sodium hydroxide (Dinâmica, H.P.) in deionized water. One-half of this alkaline solution was mixed with sodium aluminate, whose synthesis procedure is described below. The other half of the alkaline solution was mixed with fumed silica (Aerosil OX50, $100 \mathrm{wt} \%$ $\mathrm{SiO}_{2}$ ). The mixture was vigorously stirred until a thick gel was obtained. Following a proper amount of the cationic surfactant CTAB (Isofar, 98\%) was added (or not) to the initial gel under stirring, such that the $\mathrm{CTAB} / \mathrm{Al}$ molar ratio was always equal to 0.07 . The resultant gel was subsequently transferred to a Teflon-lined stainless-steel autoclave where it was heated at different crystallization times and temperatures, according to desired conditions. After heating, the sample inside the autoclave was washed with deionized water and ethanol while being vacuum filtered to stabilize the $\mathrm{pH}(\sim 10)$. Finally, the slurry formed after filtration was dried at $343 \mathrm{~K}$ for $12 \mathrm{~h}$. Sodium aluminate was synthesized as follows. First, $75 \mathrm{~g}$ of sodium hydroxide was dissolved in $100 \mathrm{~mL}$ of deionized water. Then, $75 \mathrm{~g}$ of aluminum hydroxide was added to the above solution until complete dissolution. The solution was placed in an oil bath at $372 \mathrm{~K}$, remaining in this condition under constant stirring for $1 \mathrm{~h}$. Subsequently, deionized water was added to the solution in order to complete $250 \mathrm{~mL}$. The remaining solution was then poured into a shallow Pyrex container and placed in a furnace at $343 \mathrm{~K}$ for drying. 
Characterization: X-ray diffraction (XRD) patterns were recorded with a Shimadzu XRD-6000 diffractometer employing $\mathrm{CuK} \alpha$ radiation $(\lambda=1.54056 \AA$ ) with $\mathrm{Ni}$ filter, $40 \mathrm{kV}$ voltage and $30 \mathrm{~mA}$ current. The $2 \theta$ angle was scanned from $5^{\circ}$ to $45^{\circ}$ with a scanning rate of $1.2^{\circ} \cdot \mathrm{min}^{-1}$. To determine and to quantify the formation of LTA and FAU structures, it was necessary to define two response variables. In the case of LTA, according to the collection file number 183702 of the Inorganic Crystal Structure Database (ICSD), the response variable was the area below the peak located around $29.9^{\circ}$, which was called $\mathrm{A}_{\mathrm{LTA}}$. In the case of FAU, according to the collection file number 34097 of the ICSD, the area below the peak located around $6.1^{\circ}$ was evaluated, called $\mathrm{A}_{\mathrm{FAU}}$. To proceed with the integration of the peaks, a polynomial baseline was first subtracted that allowed correcting the influence of the amorphous constituents of the samples. This procedure was performed on newly obtained data, that is, without any previous treatment, including normalizations. After subtraction of the baseline, the integrations of the peaks referring to the LTA and FAU structures were performed separately. Thermogravimetric analyses (TGA) were carried out using a Shimadzu instrument (DTG-60H). Each experiment was performed using $6 \mathrm{mg}$ of sample, with heating from room temperature to $1273 \mathrm{~K}$ with a rate of $10 \mathrm{~K} \cdot \mathrm{min}^{-1}$, under a flow of $50 \mathrm{~mL} \cdot \mathrm{min}^{-1}$ of $\mathrm{N}_{2}$. Scanning electron micrographs were obtained with an EVO MA 10 microscope at accelerating voltages of 20 and $25 \mathrm{kV}$. Samples were dispersed in acetone and the suspensions were dropped onto aluminum sample holders. Then, gold was evaporated on each sample to form a thin layer. Prior to the analyses, the samples were kept inside a desiccator for $24 \mathrm{~h}$. Energy dispersive X-ray analysis (EDX) was performed using an Oxford instrument (51-ADD0048).

\section{RESULTS AND DISCUSSION}

First experimental design: evaluated the effects of the $\mathrm{Si} / \mathrm{Al}, \mathrm{Na} / \mathrm{Al}$ and $\mathrm{H}_{2} \mathrm{O} / \mathrm{Al}$ ratios on the response variables $\mathrm{A}_{\mathrm{LTA}}$ and $\mathrm{A}_{\mathrm{FAU}}$. The crystallization temperature was set to $372 \mathrm{~K}$. The first four columns of Table I represent the design matrix of the nine syntheses of the first design. The respective XRD patterns are shown in Fig. 1; the characteristic peaks of the LTA structure are indicated by circles, while the peaks of FAU are represented by triangles. Sample P1A5 was the only one that presented characteristic peaks exclusively of the LTA structure (Fig. 1). The remaining essays led to the formation of a mixture containing the two phases, LTA and FAU, or only FAU, which is the case of synthesis P1A4. Furthermore, syntheses P1A2 and P1A4 generated a fair amount of amorphous material. A summary of the crystal structures formed on each of the nine syntheses is shown in the fifth column of Table I. Columns 6 and 7 give the areas below the peaks chosen to represent the LTA $\left(\mathrm{A}_{\mathrm{LTA}}\right)$ and FAU $\left(\mathrm{A}_{\mathrm{FAU}}\right)$ structures. The last column shows the Si/Al molar ratio of the dried products obtained by EDX analysis $\left(\mathrm{Si} / \mathrm{Al}_{\mathrm{EDX}}\right)$. Among the XRD patterns of Fig. 1, the XRD pattern of synthesis P1A1 presented the largest area under the peak situated around $29.9^{\circ}\left(\mathrm{A}_{\mathrm{LTA}}\right)$. It means that synthesis P1A1 generated the dry solid product with the highest crystallinity for the LTA structure among all syntheses of the first design. Concerning the framework of FAU, the largest area under the peak situated around $6.1^{\circ}\left(\mathrm{A}_{\mathrm{FAU}}\right)$ was found in sample P1A8.

Table I - Experimental conditions and results of the first experimental design. Variables $\mathrm{A}_{\mathrm{LTA}}$ and $\mathrm{A}_{\mathrm{FAU}}$ represent the areas under the peaks characteristic of the XRD patterns of LTA $\left(\sim 29.9^{\circ}\right)$ and FAU $\left(\sim 6.1^{\circ}\right)$, respectively. The crystallization temperature, time and the $\mathrm{CTAB} / \mathrm{Al}$ ratio were set to $372 \mathrm{~K}, 4 \mathrm{~h}$ and 0.07 , respectively.

[Tabela I - Condições experimentais e resultados do primeiro planejamento experimental. As variáveis $A_{L T A}$ e $A_{F A U}$ representam as áreas sob os picos característicos dos difratogramas de raios $X$ das estruturas LTA $\left(\sim 29,9^{\circ}\right)$ e FAU $\left(\sim 6,1^{\circ}\right)$, respectivamente. A temperatura e o tempo de cristalização e a razão CTAB/Al foram fixados em $372 \mathrm{~K}, 4 \mathrm{~h} e$ 0,07 , respectivamente.]

\begin{tabular}{cccccccc}
\hline Synthesis & $\mathrm{Si} / \mathrm{Al}$ & $\mathrm{Na} / \mathrm{Al}$ & $\mathrm{H}_{2} \mathrm{O} / \mathrm{Al}$ & Structure & $\mathrm{A}_{\mathrm{FAU}}$ & $\mathrm{A}_{\text {LTA }}$ & $\mathrm{Si} / \mathrm{Al}_{\mathrm{EDX}}$ \\
\hline $\mathrm{P} 1 \mathrm{~A} 1$ & 0.9 & 2.2 & 60.8 & FAU/LTA & 54.6 & 749.6 & 1.05 \\
$\mathrm{P}_{1 \mathrm{~A} 1}{ }^{\mathrm{a}}$ & 0.9 & 2.2 & 60.8 & LTA & $\mathrm{b}$ & 522.0 & 1.08 \\
$\mathrm{P} 1 \mathrm{~A} 2$ & 1.5 & 2.2 & 60.8 & FAU/LTA & 101.9 & 173.6 & - \\
$\mathrm{P} 1 \mathrm{~A} 3$ & 0.9 & 4.2 & 60.8 & FAU/LTA & 177.7 & 692.7 & - \\
P1A4 & 1.5 & 4.2 & 60.8 & FAU & 516.6 & $\mathrm{~b}$ & - \\
P1A5 & 0.9 & 2.2 & 97.8 & LTA & $\mathrm{b}$ & 640.4 & - \\
P1A6 & 1.5 & 2.2 & 97.8 & FAU/LTA & 115.4 & 718.1 & 1.22 \\
P1A7 & 0.9 & 4.2 & 97.8 & FAU/LTA & 262.1 & 637.4 & - \\
P1A8 & 1.5 & 4.2 & 97.8 & FAU/LTA & 1788.2 & $\mathrm{~b}$ & 1.40 \\
P1A8 & 1.5 & 4.2 & 97.8 & FAU/LTA & 675.8 & 130.0 & 1.31 \\
P1PC & 1.2 & 3.2 & 79.3 & FAU/LTA & 584.0 & 62.5 & 1.35 \\
\hline
\end{tabular}

${ }^{a}$ - samples synthesized without addition of $C T A B ;^{b}$ - unable to determine due to a lack of XRD lines. 

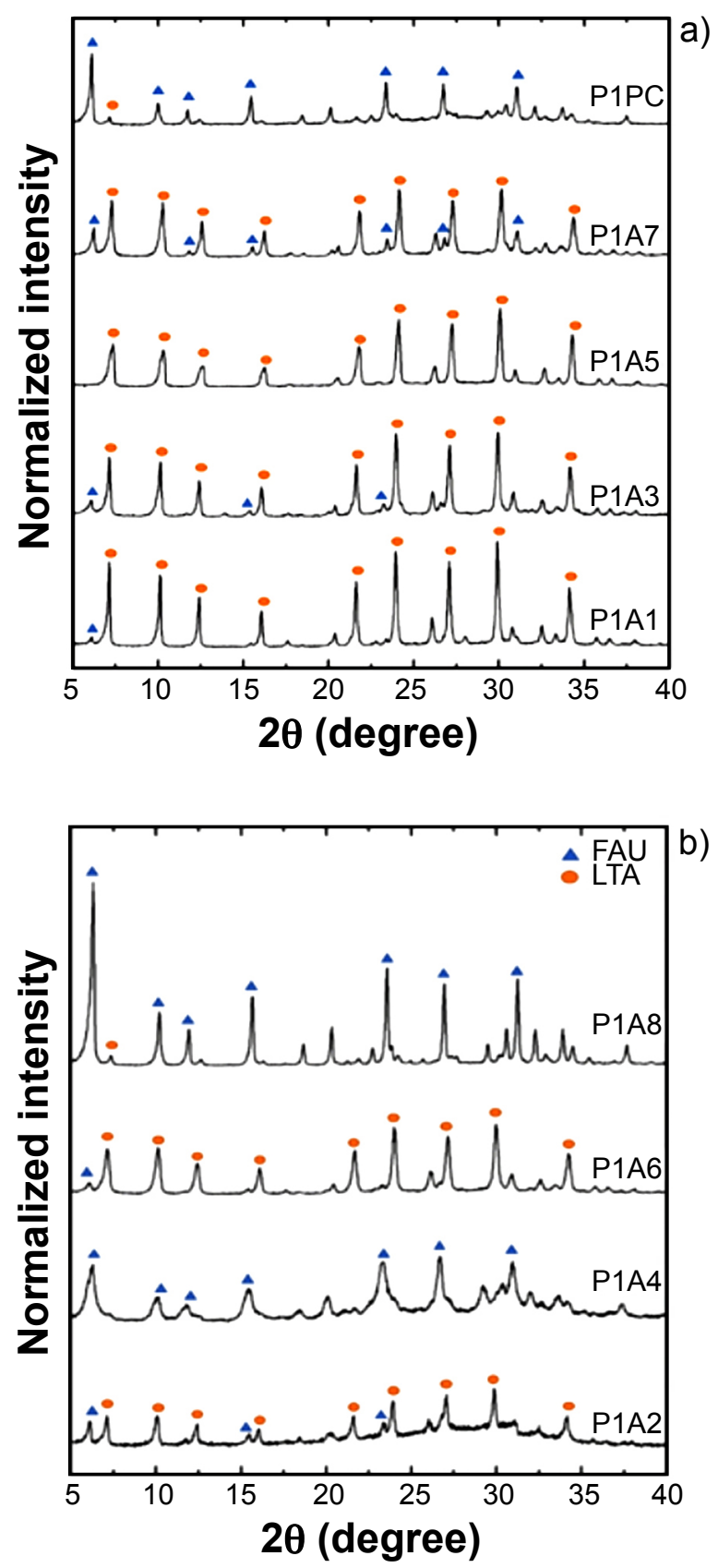

Figure 1: XRD patterns of syntheses 1-9 of the first experimental design ( $\mathrm{T}=372 \mathrm{~K})$.

[Figura 1: Difratogramas de raios $X$ das sinteses 1-9 do primeiro planejamento experimental $(T=372 \mathrm{~K})$.]

The Si/Al ratio had a very strong effect on $\mathrm{A}_{\mathrm{LTA}}$. Augmenting the $\mathrm{Si} / \mathrm{Al}$ ratio from the lower $(0.9)$ to the upper level (1.5) decreased the value of $\mathrm{A}_{\text {LTA }}$ in general. Variable $\mathrm{A}_{\mathrm{FAU}}$ followed an opposite behavior: it increased as the $\mathrm{Si} / \mathrm{Al}$ ratio increased. According to [31], there is no quantitative correlation of the $\mathrm{Si} / \mathrm{Al}$ ratio used in the synthesis and that in the final product, which means that a dry solid with certain $\mathrm{Si} / \mathrm{Al}$ ratio is not accurately obtained by simply adjusting the synthesis composition. The results of this work indicated that there is, in fact, no direct correlation between the $\mathrm{Si} / \mathrm{Al}$ ratio used in the synthesis and that obtained in the dry solid ( $\mathrm{Si} / \mathrm{Al}{ }_{\mathrm{EDX}}$, Table I). For some samples (P1A6 and $\mathrm{P} 1 \mathrm{~A} 8$ ), the $\mathrm{Si} / \mathrm{Al}$ ratio used in the synthesis was greater than the value of $\mathrm{Si} / \mathrm{Al}{ }_{\mathrm{EDX}}$, while in others (P1A1 and P1PC) the opposite was true. However, the deviation was never greater than $20 \%$. Zhan et al. [20] synthesized LTA mixed with FAU (synthesis $\mathrm{Si} / \mathrm{Al}$ ratio $=0.963$ ) and observed with Fourier transform infrared spectroscopy (FTIR) that the FAU phase in the samples was zeolite $\mathrm{X}(1<\mathrm{Si} / \mathrm{Al}<1.5)$ rather than zeolite $\mathrm{Y}(\mathrm{Si} / \mathrm{Al} \geq 1.5)$. Zeolites $\mathrm{X}$ and $\mathrm{Y}$ have identical structure types and differ only in the $\mathrm{Si} / \mathrm{Al}$ ratio in the final crystal structure [32]. In this work, the FAU phase of dry solids was estimated in the interstice between types $\mathrm{X}$ and $\mathrm{Y}$, that is, $0.9 \leq \mathrm{Si} / \mathrm{Al}_{\text {solid }} \leq 3.2$.

At this point, the effect of using or not using CTAB as a structure-directing agent can be evaluated. For this purpose, two other samples with the same conditions of syntheses P1A1 and P1A8 were synthesized, but without adding CTAB. Fig. 2 shows the XRD patterns of the dried products obtained for each of these syntheses. For comparison purposes, the XRD patterns of the samples synthesized with CTAB are also shown (the same XRD patterns of Fig. 1). The use of CTAB did not qualitatively modify the XRD patterns of the dry solids, that is, LTA and FAU remained as major phases in the products of synthesis P1A1 and P1A8, respectively. The XRD pattern of synthesis P1A1 (with CTAB) is an exception due to the presence of very small peaks characteristics of FAU. It is possible to see an increase in the crystallinity of both phases in both products, which justifies the use of CTAB as a structure-directing agent if the goal is to increase crystallinity. Quantitatively, the $\mathrm{Si} / \mathrm{Al}$ ratio of the dry solids obtained from synthesis using and not using

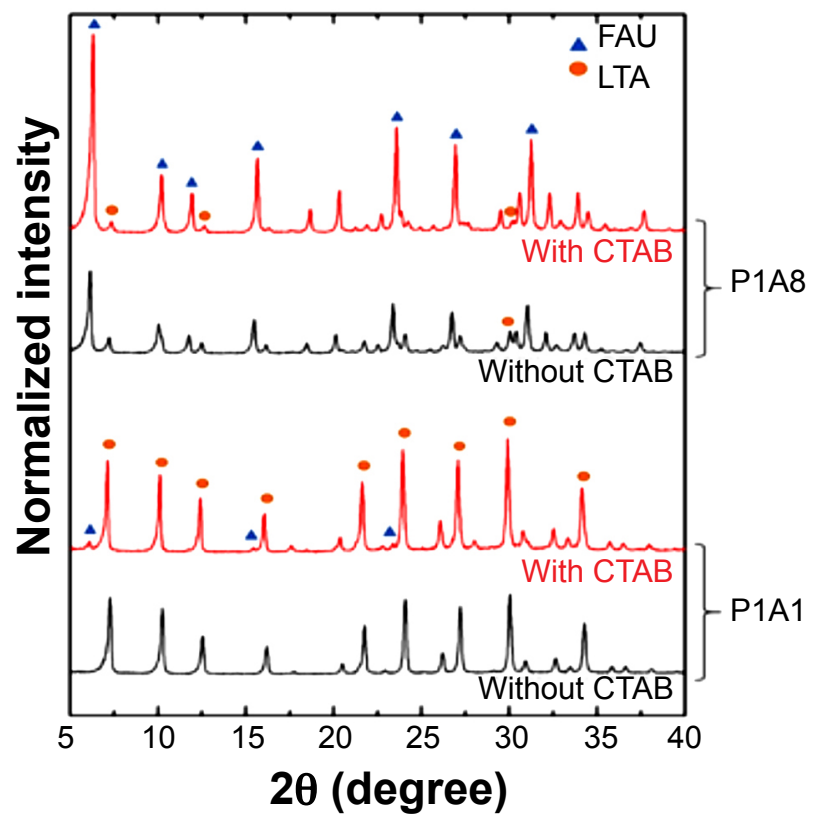

Figure 2: XRD patterns of syntheses P1A1 and P1A8 of the first experimental design with and without using $\mathrm{CTAB}$ as structuredirecting agent $(\mathrm{T}=372 \mathrm{~K})$.

[Figura 2: Difratogramas de raios $X$ das sinteses P1A1 e P1A8 do primeiro planejamento experimental com e sem a utilização de $C T A B$ como agente direcionador estrutural $(T=372 \mathrm{~K})$.] 
CTAB also did not differ substantially from one another (Table I). The P1A1 syntheses showed $\mathrm{Si} / \mathrm{Al}$ ratios ranging from 1.08 (without CTAB) to 1.05 (with CTAB), while the $\mathrm{P} 1 \mathrm{~A} 8$ syntheses resulted in $\mathrm{Si} / \mathrm{Al}$ ratios ranging from 1.31 (without CTAB) to 1.40 (with CTAB).

SEM micrographs of synthesized zeolites can be seen in Fig. 3. The crystals of sample P1A1 (Figs. 3a and 3b) were cubes with rounded edges, similar to the cubes with sharp edges of ideal LTA crystals [20]. There are no morphological differences between the crystals of Fig. 3a (synthesized with CTAB) and Fig. 3b (synthesized without CTAB), except that those of Fig. 3b appear to be slightly larger. The literature [33] also reports the synthesis of LTA crystals with approximately $1.4 \mu \mathrm{m}$ diameter, similar to those of sample P1A1, where the temperature, time and composition of the starting gel were set to $368 \mathrm{~K}, 10-15 \mathrm{~h}$ and $4.0 \mathrm{Na}_{2} \mathrm{O}: 0.3 \mathrm{Al}_{2} \mathrm{O}_{3}: 1.0 \mathrm{SiO}_{2}$ : $200 \mathrm{H}_{2} \mathrm{O}$, respectively. SEM micrographs of well-developed LTA crystals can be found in several other studies [11, 13-15, $20,33]$. On the other hand, the morphology of the crystals of sample P1A8 (Figs. 3c and 3d) was typical of faujasitetype zeolites. Faujasites usually present an octahedral shape, as demonstrated by other researchers [34], or a polyhedral shape having a generally spherical shape with some angularity developed $[32,35,36]$, which is the case of this work. Similar to synthesis P1A1 (Figs. 3a and 3b), the use of CTAB in synthesis P1A8 did not produce significant effects on the morphology of the particles. The crystals of sample P1A6 had mostly LTA structure (Fig. 3e) with sharp edges or in the form of spheres. However, although not visible in the SEM micrographs, there were also traces of faujasite, as shown by XRD analysis (Fig. $1 \mathrm{~b}$ and Table I). Although the XRD analysis of sample P1PC revealed the presence of faujasite (Fig. 1b and Table I), the crystals were dispersed in a large amount of closely aggregated nanoparticles forming irregular spherical aggregates (Fig. 3f). These aggregated nanoparticles were also observed by other researchers [21], who employed a similar synthesis methodology.

In this work, alkalinity was defined as the $\mathrm{Na} / \mathrm{Al}$ ratio. Alkalinity increases the solubility of $\mathrm{Al}$ and $\mathrm{Si}$ sources, and accelerates the polymerization of aluminate anions. Hence, the crystallization rate is directly proportional to the alkalinity of the reaction mixture $[31,37,38]$. Augmenting the $\mathrm{Na} / \mathrm{Al}$ ratio from the lower (2.2) to the upper level (4.2) decreased the value of $\mathrm{A}_{\mathrm{LTA}}$. Oppositely, variable $\mathrm{A}_{\mathrm{FAU}}$ increased as the $\mathrm{Na} / \mathrm{Al}$ ratio increased. It means that LTA and FAU competed during the crystallization process, but LTA was favored at lower alkalinities. These results go in the opposite direction of what is generally reported $[8,16]$. According to these studies, increasing the concentration of $\mathrm{Na}^{+}$ions favors the formation of LTA over FAU. The discrepancy may be due to the large difference between the values of $\mathrm{Na} / \mathrm{Al}$ used in $[8$, 16] $(\mathrm{Na} / \mathrm{Al}<1)$ and those employed in this work $(2.2<\mathrm{Na} / \mathrm{Al}$ $<4.2$ ). The effect of the $\mathrm{H}_{2} \mathrm{O} / \mathrm{Al}$ ratio on LTA/FAU selectivity was not as evident as the previous two effects, namely the $\mathrm{Si} / \mathrm{Al}$ and $\mathrm{Na} / \mathrm{Al}$ ratios. However, our data indicated that augmenting the $\mathrm{H}_{2} \mathrm{O} / \mathrm{Al}$ ratio from the lower (60.8) to the upper level (97.8) decreased the value of $\mathrm{A}_{\mathrm{LTA}}$ in general.

Thermal behaviors of samples P1A1, P1A6, P1A8 and P1PC are reported in Fig. 4. Solid lines refer to samples synthesized with the addition of CTAB, whereas dashed

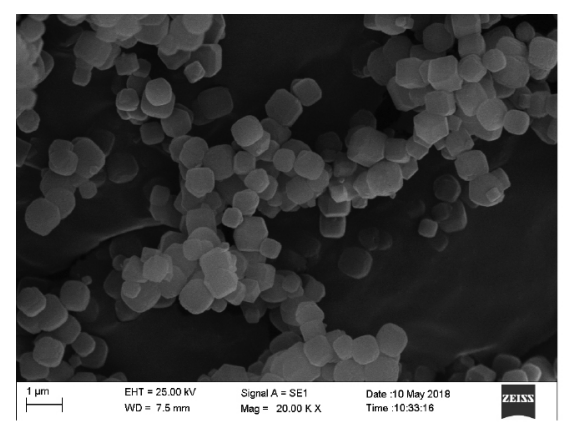

a)

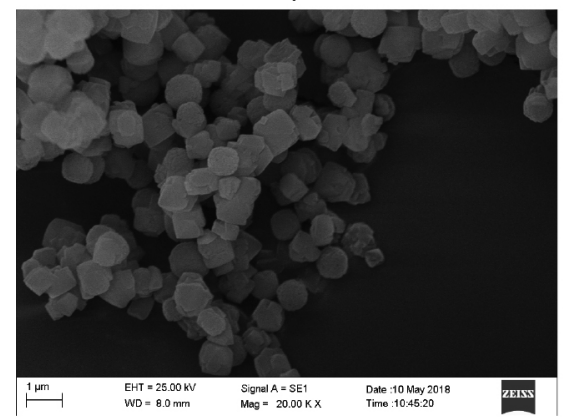

d)

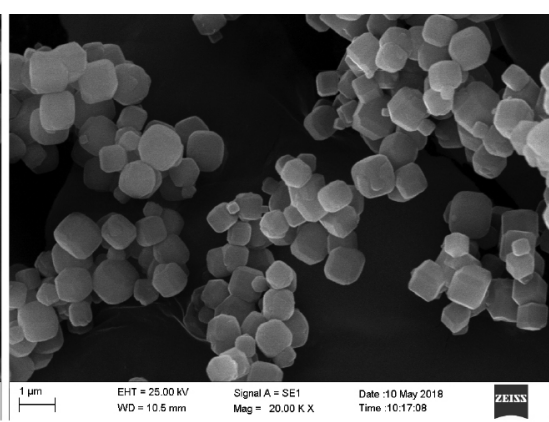

b)

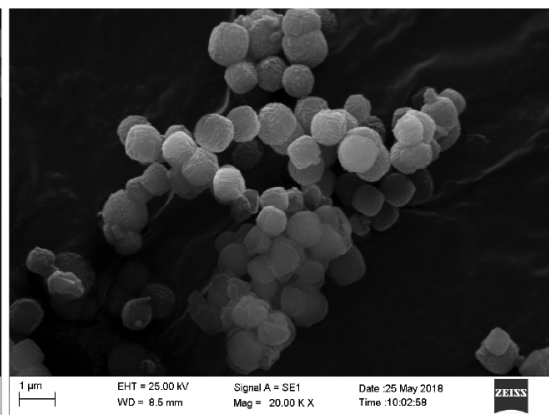

e)

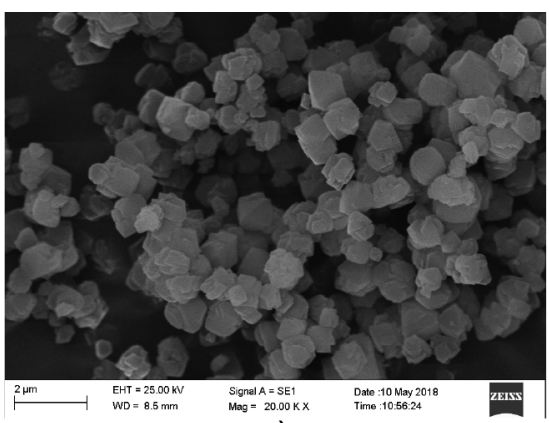

c)

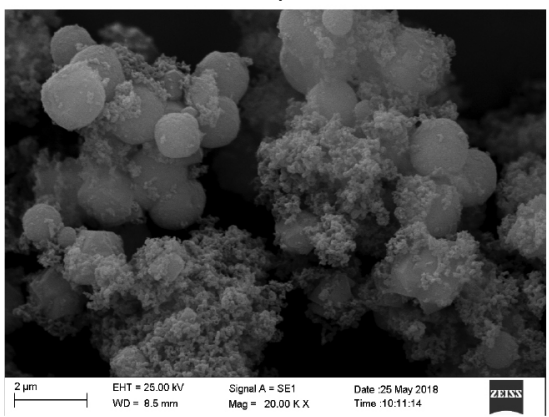

f)

Figure 3: SEM micrographs of the products of the first experimental design: a) P1A1 with CTAB; b) P1A1 without CTAB; c) P1A8 with CTAB; d) P1A8 without CTAB; e) P1A6 with CTAB; and f) P1PC with CTAB. Samples were synthesized at $372 \mathrm{~K}$.

[Figura 3: Micrografias de MEV dos produtos do primeiro planejamento experimental: a) P1A1 com CTAB; b) P1A1 sem CTAB; c) P1A8 com CTAB; d) P1A8 sem CTAB; e) P1A6 com CTAB; e f) P1PC com CTAB. As amostras foram sintetizadas a $372 \mathrm{~K}$.] 

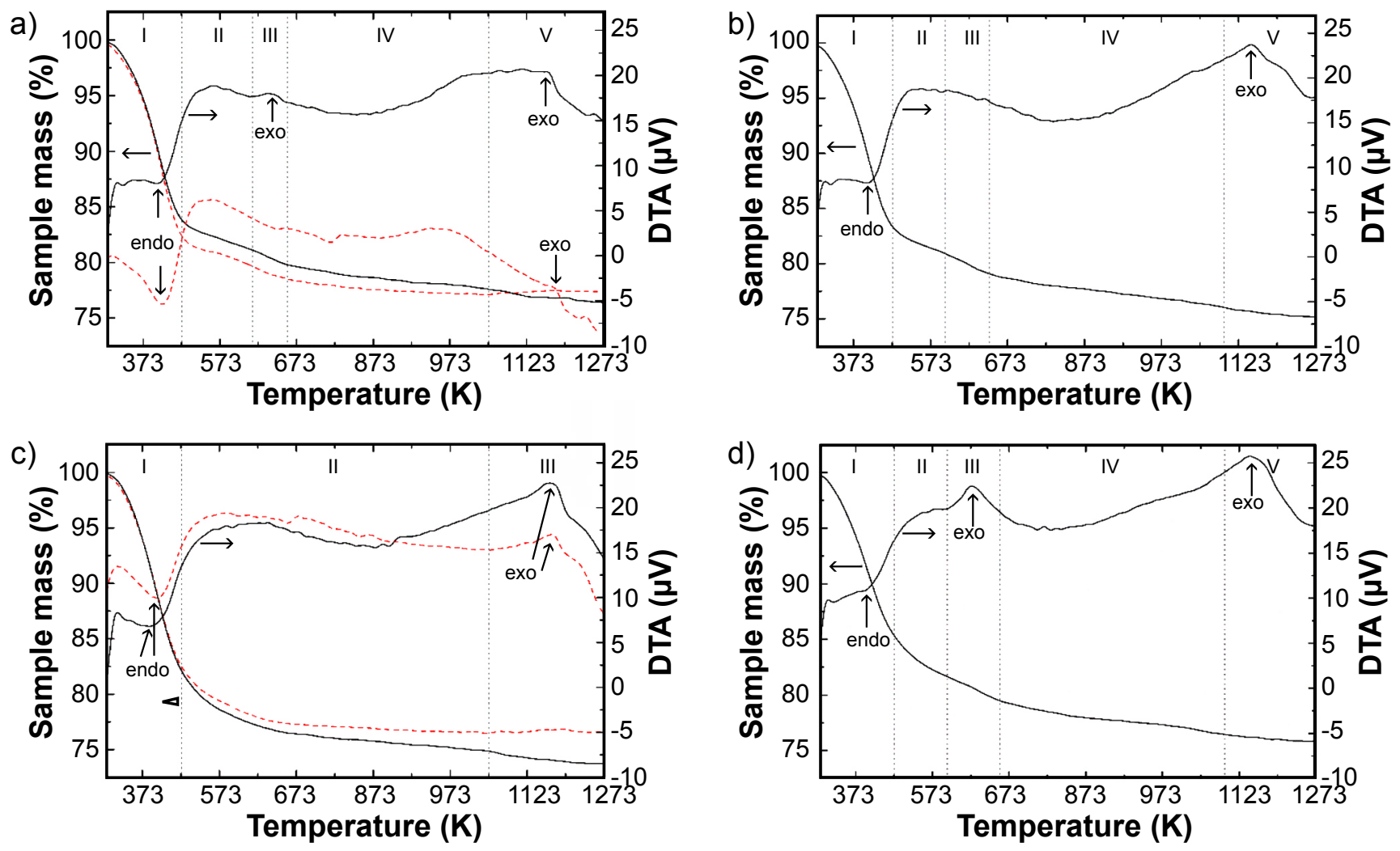

Figure 4: TGA and DTA profiles of the products of the first experimental design: a) P1A1; b) P1A6; c) P1A8; and d) P1PC. Solid lines refer to samples synthesized with the addition of CTAB, whereas dashed lines refer to samples synthesized without CTAB.

[Figura 4: Perfis de ATG e DTA dos produtos do primeiro planejamento experimental: a) P1A1; b) P1A6; c) P1A8; e d) P1PC. As linhas sólidas referem-se às amostras sintetizadas co m adição de CTAB, enquanto que as linhas tracejadas referem-se às amostras sintetizadas sem CTAB.]

lines refer to samples synthesized without CTAB. The TGA profiles of all samples, with or without the addition of CTAB, showed a first stage (I) of mass loss up to approximately 450 $\mathrm{K}$, as also evidenced by the endothermic peaks in the DTA profiles (indicated by open arrows). The mass loss in this first stage occurred at a very high rate, reaching on average $16 \%$ of the initial mass, and may be related to loss of external, loosely bound water [32]. The mass loss of sample P1A8 (Fig. 4c) can be divided into three stages, the first of which (stage I) has already been described previously. In stage II, mass loss occurred at a much lower rate and may be due to loss of more tightly bounded water molecules in sodalite cages [33]. The rate remained constant up to $1047 \mathrm{~K}$, when it increased again, in stage III. This third stage was associated with an exothermic peak in the DTA profile at $1170 \mathrm{~K}$, probably caused by the destruction of the crystal lattice of the zeolite [39]. The mass loss of samples P1A1, P1A6 and P1PC can be divided into five stages. The mass losses of stages I and II were described in the previous paragraphs. Stage III was probably related to the combustion of CTAB, evidenced by the strong exothermic peak at $600 \mathrm{~K}$ in the DTA profile of sample P1PC (Fig. 4d), and by a weaker peak at $623 \mathrm{~K}$ in the DTA profile of sample P1A1 synthesized with CTAB (solid line in Fig. 4a). Although the amount of CTAB used in the syntheses was very small $(\mathrm{CTAB} / \mathrm{Al}=0.07)$, the DTA profile of sample P1A1 synthesized without CTAB (dashed line in Fig. 4a) showed no evidence of the exothermic peak within stage III, indicating that CTAB was in fact burned in the samples synthesized with this substance. In a similar work [16], an exothermic peak in the DSC profile, located between 573 and $593 \mathrm{~K}$, was attributed to the combustion of tetramethylammonium hydroxide (TMAOH) located near the crystal external zeolite surface. In stage IV, the loss of strongly adsorbed water (initiated in stage II) continued to occur. Finally, in stage V, the crystal lattice of the zeolite was destroyed.

The results shown and discussed up to this point indicate that CTAB should not be acting as a structuredirecting agent, perhaps because of the low amount used in the syntheses $(\mathrm{CTAB} / \mathrm{Al}=0.07)$. Indeed, due to this small amount of CTAB, only the DTA profiles of the P1A1 (with CTAB) and P1PC syntheses (Figs. 3a and 3d, respectively) evidenced a possible CTAB burn in the region between 600 and $623 \mathrm{~K}$. Besides, regardless of the addition of CTAB, the compositions of the products of syntheses P1A1 and P1A8 were very similar. For instance, synthesis P1A1 (with and without CTAB) was composed of LTA with traces of FAU; and synthesis P1A8 (with and without CTAB) was composed of FAU with traces of LTA (Fig. 2 and Table I). On the other hand, CTAB may be acting as a growth modifier, i.e., substances capable of interacting with crystal surfaces and influencing their growth rates [34]. Although the SEM 
micrographs do not demonstrate significant differences in the sizes of LTA (Figs. 3a and 3b) and FAU (Figs. 3c and 3d) crystals, the XRD peaks of the respective phases increased considerably in the presence of CTAB (Fig. 2).

Second experimental design: was conducted to study the effects of the $\mathrm{Si} / \mathrm{Al}$ and $\mathrm{H}_{2} \mathrm{O} / \mathrm{Al}$ ratios, and the crystallization time on $\mathrm{A}_{\mathrm{LTA}}$ and $\mathrm{A}_{\mathrm{FAU}}$. The crystallization temperature was set to $372 \mathrm{~K}$. The first four columns of Table II represent the design matrix of the nine syntheses of the second design. The respective XRD patterns are shown in Fig. 5. As occurred in the first design, $\mathrm{A}_{\mathrm{LTA}}$ decreased and $\mathrm{A}_{\mathrm{FAU}}$ increased with the increase of the $\mathrm{Si} / \mathrm{Al}$ ratio. On the other hand, the behavior of $\mathrm{A}_{\mathrm{LTA}}$ and $\mathrm{A}_{\mathrm{FAU}}$ with the crystallization time was not so simple. The first fact highlighted is that the induction period of all the samples, including the samples of the first design, was at least less than $4 \mathrm{~h}$. These results corroborate the work of Oleksiak et al. [29], who synthesized FAU/ LTA zeolites with $\mathrm{Si} / \mathrm{Al}$ ratios of either 2 or 5 and $\mathrm{Na} / \mathrm{Al}$ ratios varying from 2.7 to 50 . In most syntheses, the authors obtained amorphous material in the first $2 \mathrm{~h}$ of heating, while crystalline phases began to occur only after $3 \mathrm{~h}$. For some specific conditions, LTA was the first phase formed,

Table II - Experimental conditions and results of the second experimental design. Variables $\mathrm{A}_{\mathrm{LTA}}$ and $\mathrm{A}_{\mathrm{FAU}}$ represent the areas under the peaks characteristic of the XRD patterns of LTA $\left(\sim 29.9^{\circ}\right)$ and FAU $\left(\sim 6.1^{\circ}\right)$, respectively. The crystallization temperature and the $\mathrm{Na} / \mathrm{Al}$ and $\mathrm{CTAB} / \mathrm{Al}$ ratios were set to $372 \mathrm{~K}, 3.2$ and 0.07 , respectively.

[Tabela II - Condições experimentais e resultados do segundo planejamento experimental. As variáveis $A_{L T A}$ e $A_{F A U}$ representam as áreas sob os picos característicos dos difratogramas de raios X das estruturas LTA $\left(\sim 29,9^{\circ}\right)$ e FAU $\left(\sim 6,1^{\circ}\right)$, respectivamente. A temperatura de cristalização e as razões Na/Al e CTAB/Al foram fixadas em $372 \mathrm{~K}, 3,2 \mathrm{e}$ 0,07 , respectivamente.]

\begin{tabular}{ccccccc}
\hline Synthesis & $\mathrm{Si} / \mathrm{Al}$ & $\mathrm{H}_{2} \mathrm{O} / \mathrm{Al}$ & Time $(\mathrm{h})$ & Structure & $\mathrm{A}_{\text {FAU }}$ & $\mathrm{A}_{\text {LTA }}$ \\
\hline $\mathrm{P} 2 \mathrm{~A} 1$ & 0.9 & 60.8 & 4 & FAU/LTA & 1662.9 & 474.0 \\
$\mathrm{P} 2 \mathrm{~A} 2$ & 1.5 & 60.8 & 4 & FAU & 2173.8 & $\mathrm{a}$ \\
$\mathrm{P} 2 \mathrm{~A} 3$ & 0.9 & 60.8 & 8 & FAU/LTA & 85.1 & 1202.8 \\
P2A4 & 1.5 & 60.8 & 8 & FAU & 2028.2 & $\mathrm{a}$ \\
P2A5 & 0.9 & 97.8 & 4 & FAU/LTA & 103.6 & 552.9 \\
P2A6 & 1.5 & 97.8 & 4 & FAU/LTA & 543.8 & 36.7 \\
P2A7 & 0.9 & 97.8 & 8 & FAU/LTA & 610.7 & 837.7 \\
P2A8 & 1.5 & 97.8 & 8 & FAU/LTA & 2043.0 & 55.7 \\
P2PC & 1.2 & 79.3 & 6 & FAU/LTA & 2331.3 & 142.6 \\
\hline
\end{tabular}

$a_{-}$- unable to determine due to a lack of XRD lines.

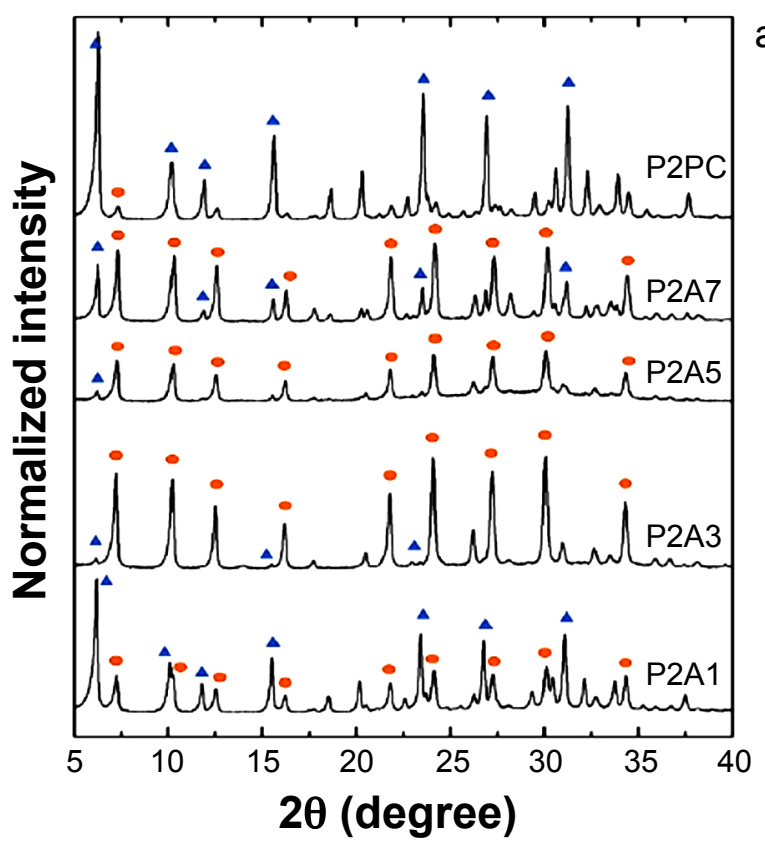

a)

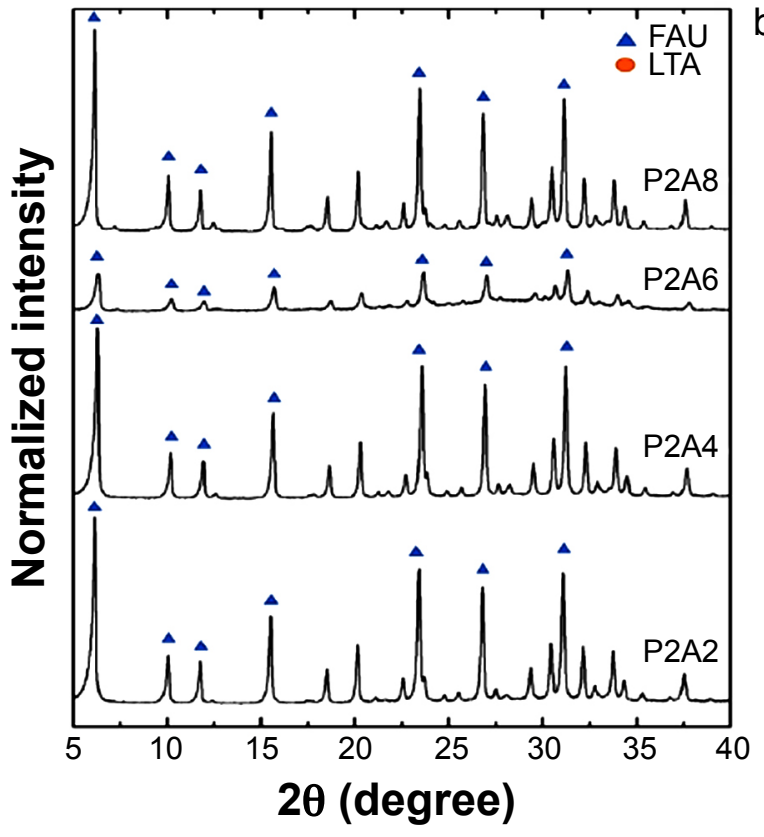

Figure 5: XRD patterns of syntheses 1-9 of the second experimental design ( $\mathrm{T}=372 \mathrm{~K})$.

[Figura 5: Difratogramas de raios $X$ das sinteses 1-9 do segundo planejamento experimental ( $T=372 \mathrm{~K})$.] 
followed by an intercrystalline transformation to FAU at the longer heating time. In other cases, the FAU phase was the first obtained, but the product did not change after long heating periods. According to [8], FAU requires a longer time to crystallize due to its more complex and larger silicate units (D6R) and sparser structure. This situation is similar to that reported by Zhang et al. [40], who synthesized LTA/ FAU composites at $363 \mathrm{~K}$ and observed a fast crystallization rate of a single FAU phase between 7 and $15 \mathrm{~h}$ (see Fig. 1 of respective paper). Further prolonging the crystallization time did not lead to higher crystallinity. Returning to the results of this work, the crystallization time appeared to interact with the $\mathrm{H}_{2} \mathrm{O} / \mathrm{Al}$ ratio. For instance, when the $\mathrm{H}_{2} \mathrm{O} / \mathrm{Al}$ ratio is in the upper level (97.8), an increase in the crystallization time tended to increase the crystallinity of FAU phase, which can be seen by comparing syntheses $\mathrm{P} 2 \mathrm{~A} 5 / \mathrm{P} 2 \mathrm{~A} 7$ and $\mathrm{P} 2 \mathrm{~A} 6 /$ P2A8. More specifically, the initial formation of the LTA phase was observed after $4 \mathrm{~h}$ of heating (synthesis P2A5), followed by intercrystalline transformation to FAU after 8 $h$ of heating. On the other hand, when the $\mathrm{H}_{2} \mathrm{O} / \mathrm{Al}$ ratio was in the lower level (60.8), an increase in the crystallization time tended to increase the crystallinity of LTA phase and decrease the crystallinity of FAU. This effect can be seen by comparing syntheses $\mathrm{P} 2 \mathrm{~A} 1 / \mathrm{P} 2 \mathrm{~A} 3$ and $\mathrm{P} 2 \mathrm{~A} 2 / \mathrm{P} 2 \mathrm{~A} 4$. These data contradict all previous discussion and should be the subject of further research.

Third experimental design: was carried out to assess the effect of temperature on the crystallization of the LTA and FAU phases. For this purpose, gels with the same compositions as those previously used in the P1A1 and P1A8 syntheses, with CTAB (Table I), were prepared. The only difference was that, in this case, the syntheses were performed at 372, 402, 432 and $462 \mathrm{~K}$. The respective XRD patterns of the dry products are shown in Fig. 6, while the conditions and some results (structures and $\mathrm{Si} / \mathrm{Al}_{\mathrm{EDX}}$ ) are presented in Table III. SEM micrographs of some syntheses are shown in Fig. 7. In Fig. 6a (sample P1A1), a product with almost pure LTA structure (with traces of FAU) was formed at $372 \mathrm{~K}$. As the temperature increased to $402 \mathrm{~K}$, some diffraction peaks belonging to the sodalite (SOD) structure appeared, so that pure sodalite was generated at $432 \mathrm{~K}$. The sodalite appeared as needle-shaped hexagonal crystals growing from larger crystals, which were likely remnants of the transformation of the LTA phase into sodalite (Fig. 7a). A further increase in temperature led to the formation of a mixture of sodalite (SOD), cancrinite (CAN), and nepheline (NEP) (Fig. 6a), a framework aluminosilicate described by the ideal formula $\mathrm{Na}_{3} \mathrm{~K}\left(\mathrm{AlSiO}_{4}\right)_{4}$. In the SEM micrograph of Fig. $7 b$ it is not possible to differentiate NEP (described in [41]) from SOD crystals, since they appear to have similar morphologies. The sequences of transitions previously described for sample P1A1 are in accordance with the Ostwald rule of stages [27], going from low (less stable) to high-density (more stable) structures. It was also reported [27] that phase transformations in Al-rich solutions $(\mathrm{Si} / \mathrm{Al}<1)$, which is the case of sample P1A1 ( $\mathrm{Si} / \mathrm{Al}=0.9$; Table III), tend to follow the sequence LTA (a less dense and less stable structure) $\rightarrow$ SOD $\rightarrow$ CAN (denser and more stable). In Fig. 6b (sample P1A8), a product with almost pure FAU (with traces of LTA) was formed at $372 \mathrm{~K}$. The increase in temperature led to the gradual recrystallization of the material, first in sodalite (at 402 and $432 \mathrm{~K}$ ) and finally in cancrinite (at $462 \mathrm{~K}$ ). In this case, the sodalite crystals obtained in the synthesis performed at $432 \mathrm{~K}$ (Fig. 7c) were not as euhedral as those obtained at the same temperature for sample P1A1 (Fig. 7a). However, the phase transformations also obeyed the Ostwald rule of stages, going from less dense and less stable structures, and culminating in denser
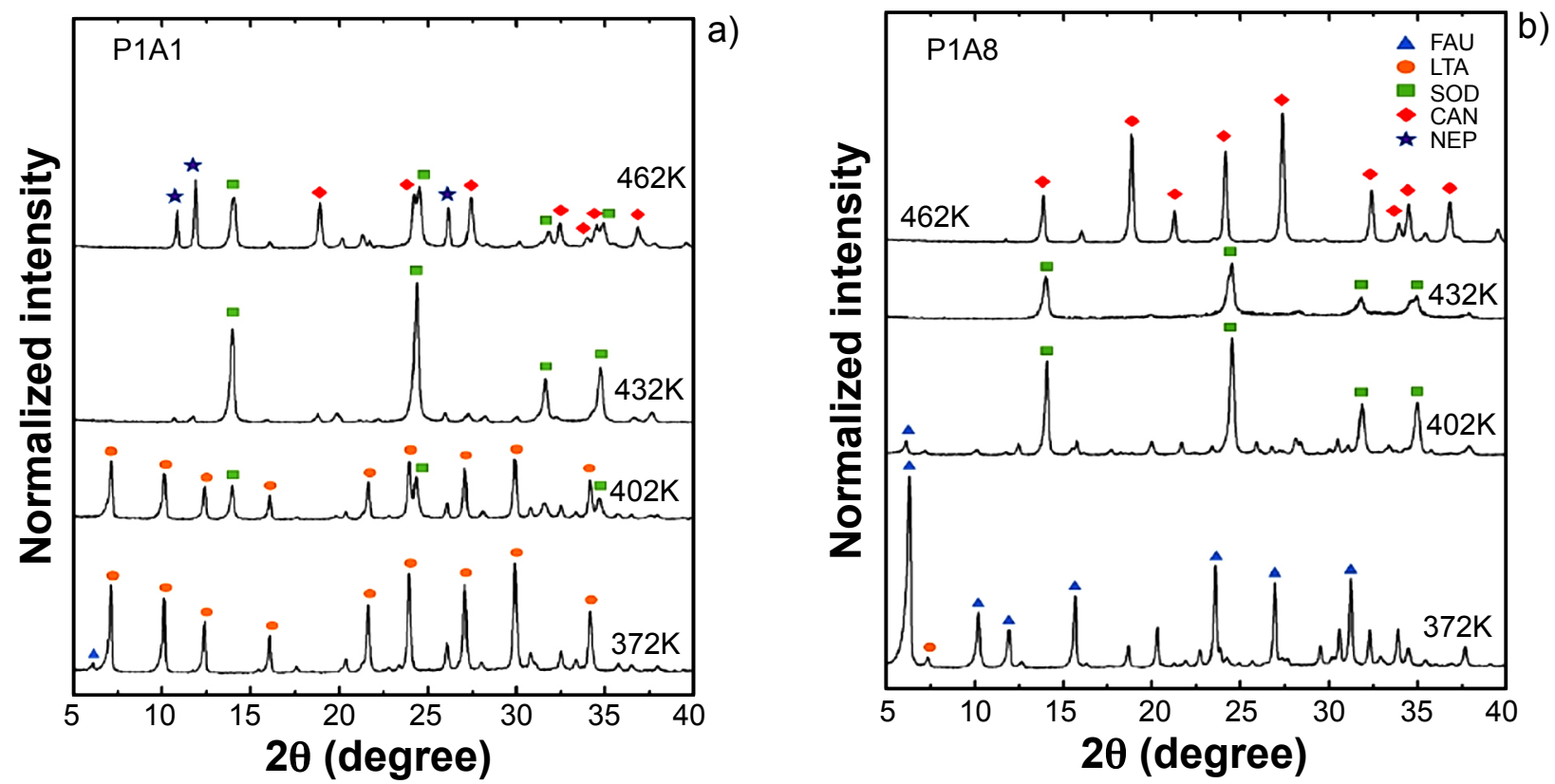

Figure 6: XRD patterns of the third experimental design: syntheses P1A1 (a) and P1A8 (b).

[Figura 6: Difratogramas de raios $X$ do terceiro planejamento experimental: sínteses P1A1 (a) e P1A8 (b).] 
Table III - Experimental conditions and results of the third experimental design. The crystallization time and $\mathrm{CTAB} / \mathrm{Al}$ ratio were set to $4 \mathrm{~h}$ and 0.07 , respectively.

[Tabela III - Condições experimentais e resultados do terceiro planejamento experimental. $O$ tempo de cristalização e a razão CTAB/Al foram fixados em 4 he 0,07, respectivamente.]

\begin{tabular}{|c|c|c|c|c|c|c|}
\hline Synthesis & $\mathrm{Si} / \mathrm{Al}$ & $\mathrm{Na} / \mathrm{Al}$ & $\mathrm{H}_{2} \mathrm{O} / \mathrm{Al}$ & $\mathrm{T}(\mathrm{K})$ & Structure & $\mathrm{Si} / \mathrm{Al}_{\mathrm{EDX}}$ \\
\hline \multirow{4}{*}{ P1A1 } & \multirow{4}{*}{0.9} & \multirow{4}{*}{2.2} & \multirow{4}{*}{60.8} & 372 & LTA/traces of FAU & 1.05 \\
\hline & & & & 402 & LTA/SOD & - \\
\hline & & & & 432 & SOD & 1.08 \\
\hline & & & & 462 & SOD/CAN/NEP & 1.13 \\
\hline \multirow{4}{*}{ P1A8 } & \multirow{4}{*}{1.5} & \multirow{4}{*}{4.2} & \multirow{4}{*}{97.8} & 372 & FAU/traces of LTA & 1.31 \\
\hline & & & & 402 & $\mathrm{SOD} /$ traces of FAU & - \\
\hline & & & & 432 & SOD & 1.09 \\
\hline & & & & 462 & CAN & - \\
\hline
\end{tabular}

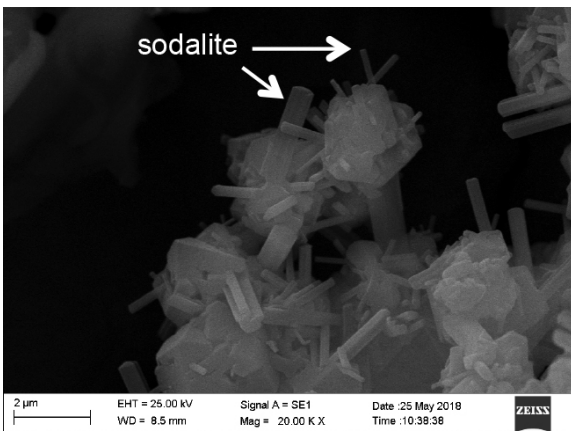

a)

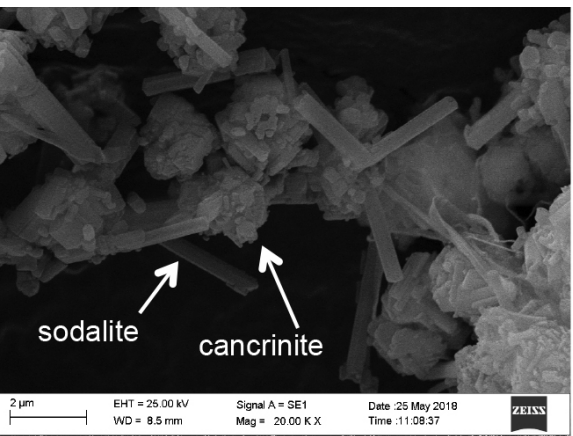

b)

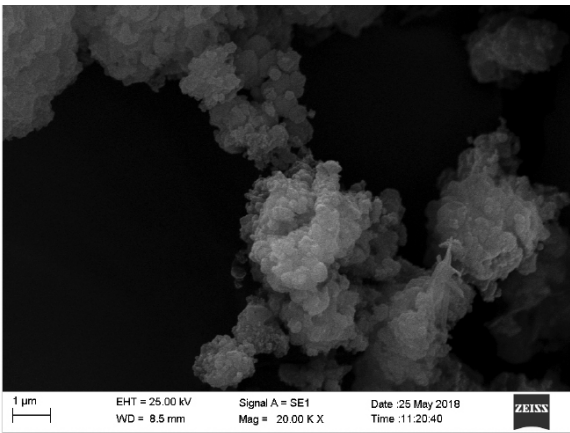

c)

Figure 7: SEM micrographs of the products of the third experimental design: a) P1A1 synthesized at $432 \mathrm{~K}$; b) P1A1 synthesized at $462 \mathrm{~K}$; and c) P1A8 synthesized at $432 \mathrm{~K}$.

[Figura 7: Micrografias eletrônicas de varredura dos produtos do terceiro planejamento experimental: a) P1A1 sintetizado em 432 K; b) PlAl sintetizado em $462 \mathrm{~K}$; e c) PlA8 sintetizado em $432 \mathrm{~K}$.]

and more stable structures (FAU $\rightarrow$ SOD $\rightarrow$ CAN). The results of this work agreed with other publications [42-44], which show that, after recrystallization of the LTA phase, sodalite forms first and then slowly converts to cancrinite at a rate that increases with increasing temperature.

\section{CONCLUSIONS}

Three experimental designs were performed to assess the effects of $\mathrm{Si} / \mathrm{Al}, \mathrm{Na} / \mathrm{Al}$ and $\mathrm{H}_{2} \mathrm{O} / \mathrm{Al}$ ratios, crystallization time and temperature on the yield of LTA and FAU phases. The syntheses were carried out with a hydrothermal method in the presence of cetyltrimethylammonium bromide (CTAB), which did not act as a structure-directing agent, but rather as a growth modifier, increasing the growth rate of LTA and FAU crystals. In most syntheses carried out at low temperature ( $372 \mathrm{~K})$, LTA and FAU competed during the crystallization process, and the products gradually changed from LTA to FAU when augmenting the $\mathrm{Si} / \mathrm{Al}, \mathrm{Na} / \mathrm{Al}$ and $\mathrm{H}_{2} \mathrm{O} / \mathrm{Al}$ ratios. The increase in temperature led to the recrystallization of the less dense and unstable LTA and FAU phases in denser and more stable phases, first in sodalite and finally in cancrinite. The increase in temperature accelerated the kinetics of recrystallization, whose phase transformation sequence respected the Ostwald rule of stages.

\section{ACKNOWLEDGMENTS}

The authors would like to thank FAPEMIG (Fundação de Amparo à Pesquisa do Estado de Minas Gerais, grant numbers APQ-01009-16 and IC-FAPEMIG2012-0451) for financial support. Prof. Carlos Henrique Ataíde (FEQ/UFU), Roni Marcos dos Santos (IQ/UFU) and the Multi-User Laboratory of the Federal University of Uberlândia (UFU) are also acknowledged.

\section{REFERENCES}

[1] E.J.M. Hensen, J.A.R. van Veen, Catal. Today. 86, 1-4 (2003) 87.

[2] W. Vermeiren, J.P. Gilson, Top. Catal. 52, 9 (2009) 1131.

[3] D.F. Plant, G. Maurin, I. Deroche, L. Gaberova, P.L. Llewellyn, Chem. Phys. Lett. 426, 4-6 (2006) 387.

[4] S.M. Auerbach, K.A. Carrado, P.K. Dutta, Handbook of zeolite science and technology, CRC Press, New York (2003).

[5] L.B. McCusker, C. Baerlocher, in: Studies in surface science and catalysis, Eds. H. van Bekkum, E.M. Flanigen, 
J.C. Jansen, Elsevier (2001) 37.

[6] F.J. Luna, U. Schuchardt, Quim. Nova 24 (2001) 885.

[7] M. Jafari, A. Nouri, M. Kazemimoghadam, T. Mohammadi, Powder Technol. 237 (2013) 442.

[8] L. Hu, S. Xie, Q. Wang, S. Liu, L. Xu, Sci. Technol. Adv. Mat. 10, 1 (2009) 015001.

[9] T.F. Chaves, H.O. Pastore, D. Cardoso, Micropor. Mesopor. Mat. 161 (2012) 67.

[10] R. Grizzetti, G. Artioli, Micropor. Mesopor. Mat. 54, 1-2 (2002) 105.

[11] A.R. Loiola, J.C.R.A. Andrade, J.M. Sasaki, L.R.D. da Silva, J. Colloid Interf. Sci. 367, 1 (2012) 34.

[12] A.L. Yonkeu, G. Miehe, H. Fuess, A.M. Goossens, J.A. Martens, Micropor. Mesopor. Mat. 96, 1-3 (2006) 396.

[13] C.A. Ríos, C.D. Williams, M.A. Fullen, Appl. Clay Sci. 42, 3-4 (2009) 446.

[14] H. Tanaka, Y. Sakai, R. Hino, Mater. Res. Bull. 37, 11 (2002) 1873.

[15] C.S. Carr, D.F. Shantz, Micropor. Mesopor. Mat. 85, 3 (2005) 284.

[16] S. Yang, Q. Li, M. Wang, A. Navrotsky, Micropor. Mesopor. Mat. 87, 3 (2006) 261.

[17] S. Mintova, V. Valtchev, in: Studies in surface science and catalysis, Eds. I. Kiricsi, G. Pál-Borbély, J.B. Nagy, H.G. Karge, Elsevier (1999) 141.

[18] H.-X. Li, J.N. Armor, Microporous Mater. 9, 1-2 (1997) 51.

[19] G.H. Kühl, Zeolites 7, 5 (1987) 451.

[20] Y. Zhan, X. Li, Y. Zhang, L. Han, Y. Chen, Ceram. Int. 39, 5 (2013) 5997.

[21] F. Hasan, R. Singh, G. Li, D. Zhao, P.A. Webley, J. Colloid Interf. Sci. 382, 1 (2012) 1.

[22] M. Mańko, R. Chal, P. Trens, D. Minoux, C. Gérardin, W. Makowski, Micropor. Mesopor. Mat. 170 (2013) 243.

[23] J. Zhang, W. Yan, H. Ding, Y. Liu, K. Tang, J. Yu, R. $\mathrm{Xu}$, in: Studies in surface science and catalysis, Eds. R. Xu, Z. Gao, J. Chen, W. Yan, Elsevier (2007) 475.

[24] T. Moteki, S.H. Keoh, T. Okubo, Chem. Commun. 50, 11 (2014) 1330.

[25] A. Chawla, R. Li, R. Jain, R.J. Clark, J.G. Sutjianto, J.C. Palmer, J.D. Rimer, Mol. Syst. Des. Eng. 3, 1 (2018) 159.

[26] G. Zhu, S. Qiu, J. Yu, Y. Sakamoto, F. Xiao, R. Xu, O. Terasaki, Chem. Mater. 10, 6 (1998) 1483.
[27] M. Maldonado, M.D. Oleksiak, S. Chinta, J.D. Rimer, J. Am. Chem. Soc. 135, 7 (2013) 2641.

[28] J. Šefčík, A.V. McCormick, Chem. Eng Sci. 54, 15 (1999) 3513.

[29] M.D. Oleksiak, J.A. Soltis, M.T. Conato, R.L. Penn, J.D. Rimer, Chem. Mater. 28, 14 (2016) 4906.

[30] R.W. Thompson, K.C. Franklin, in: Verified synthesis of zeolitic materials, Eds. R. Harry, L.K. Petter, Elsevier Sci., Amsterdam (2001) 179.

[31] J. Yu, in: Studies in surface science and catalysis, Eds. J. Čejka, H. van Bekkum, A. Corma, F. Schüth, Elsevier (2007) 39

[32] K. Wang, R.C. Lemon, J.S. Buchanan, C.E. Kliewer, W.J. Roth, "Aggregates of small particles of synthetic faujasite zeolite", Patent US20120227584A1 (2012).

[33] H. Tounsi, S. Mseddi, S. Djemel, Phys. Proc. 2, 3 (2009) 1065.

[34] H. Hui, J. Gao, G. Wang, P. Liu, K. Zhang, J. Brazil. Chem. Soc. 25 (2014) 65.

[35] H. Funakoshi, Y. Shirakura, "Fine low silica faujasite type zeolite and process for its production", Patent US6306363B1 (2001).

[36] B.-Z. Zhan, M.A. White, K.N. Robertson, T.S. Cameron, M. Gharghouri, Chem. Commun. 13 (2001) 1176.

[37] L. Zhang, S. Liu, S. Xie, L. Xu, Micropor. Mesopor. Mat. 147, 1 (2012) 117.

[38] F. Hamidi, F. Boukli-Hacène, T. Cacciaguerra, A. Bengueddach, F. Di Renzo, Micropor. Mesopor. Mat. 153 (2012) 59 .

[39] A.M. Garrido Pedrosa, M.J.B. Souza, D.M.A. Melo, A.G. Souza, A.S. Araujo, J. Therm. Anal. Calorim. 79, 2 (2005) 439.

[40] X. Zhang, D. Tang, M. Zhang, R. Yang, Powder Technol. 235 (2013) 322.

[41] T.B. Kosova, L.N. Demyanets, Crystallogr. Rep. 45, 6 (2000) 1049.

[42] C.A.R. Reyes, C. Williams, O.M.C. Alarcón, Mater. Res. 16 (2013) 424.

[43] M.C. Barnes, J. Addai-Mensah, A.R. Gerson, Micropor. Mesopor. Mat. 31, 3 (1999) 287.

[44] Y. Deng, J.B. Harsh, M. Flury, J.S. Young, J.S. Boyle, Appl. Geochem. 21, 8 (2006) 1392.

(Rec. 17/01/2018, Rev. 16/03/2018, 09/06/2018, Ac. 23/07/2018) 